"Mircea cel Batran" Naval Academy Scientific Bulletin, Volume XIX - 2016 - Issue 2 The journal is indexed in: PROQUEST / DOAJ / Crossref / EBSCOhost / INDEX COPERNICUS / DRJI / OAJI / JOURNAL INDEX I I2OR / SCIENCE LIBRARY INDEX / Google Scholar I Academic Keys/ ROAD Open Access I Academic Resources / Scientific Indexing Services / SCIPIO / JIFACTOR

\title{
NAVAL OPERATIONAL LEADERSHIP AND EMOTIONAL INTELLIGENCE
}

\author{
Carmen Luminita COJOCARU ${ }^{1}$ \\ ${ }^{1}$ Associate Professor Ph.D. "Mircea cel Batran" Naval Academy, Constanta, Romania
}

\begin{abstract}
The study aims to analyze the conceptual boundaries of the two concepts operational leadership and emotional intelligence in terms of their coincidence in understanding the opposition of the following terms: part - whole, proximate kind/ type- specific difference, and their complementarity and integration into a mixed model of naval operational leadership, having as essential variable the emotional intelligence $-a$ special skill of any leader.

The findings of the theoretical and methodological analysis have major implications for the practical naval domain, i.e. for building excellence in leadership, for systematic training, so as to develop emotional intelligence, which would implicitly lead to increased safety and efficiency of the missions in the naval field.

Key words: naval operational leadership, emotional intelligence, personality.
\end{abstract}

\section{ARGUMENT}

Joining these two concepts, naval operational leadership and emotional intelligence may seem paradoxical at first sight since the first of them finds its most appropriate meaning in the technical naval field, while the latter has a purely humanistic meaning. Beyond any appearance, these two concepts are interdisciplinary, reconciling, complementing each other in a unitary whole which we may call human and professional effectiveness.

In the modern context of rapid change, the high demands of competitiveness and insecurity of employment where the focus is on transferable skills and performance, management teams and leadership have agreed a new selection paradigm able to quickly assess the predisposition to become an excellent performer vs. the anticipation of failure.

The new evaluation and anticipation grid considers the technical, intellectual and professional skills as inherent and easy to obtain through work experience in a certain field; it investigates the attributes of personality traits associated with professional success, i.e. intrinsic motivation, initiative, sociability, socialization, ability to work in teams, openness to authentic communication and adaptability.

All these "ingredients", essential to success in career, are leading us both towards naval leader's skills, and to what we call emotional intelligence. Therefore, a naval leader with emotional intelligence or a naval leader emotional intelligent is expected to do well, to perform in dealing with his team; it is also, equally predictable for his teamwork, psychosocial work climate, high motivation for success to potentiate the personality of the group, and lead them to carry out any mission, irrespective of difficulty, risk, stress or uncertainty.

\section{ESSENTIAL ATTRIBUTES OF EMOTIONAL INTELLIGENCE IN NAVAL LEADERSHIP}

We approach naval operational leadership from a broader perspective, i.e. that of the phenomenon of social influence, in which a social actor exerts a positive influence over other social actors with the explicit aim of achieving the organization's objectives.

So, in the naval crew, the leader is the one who psychologically acts on his followers in order to organize, change, integrate and achieve superior quality of their activities, in the naval field.

The psychological action over the target to be influenced is achieved through the cognitive systems, with the role of intellect labour (at the level of attitudinal systems, within the area of character traits - with an adaptative and conscious role) and also at the level of effective systems, of the behavioral - action level.

It is easy to realize that the desirable effects from the psycho-behavioral point of view are a consequence of the change in the attitudinal segments that support and guide the behavioral activism.

By carefully analyzing the structure of an attitude, some authors, including M. Zlate, believe that the predominant elements in their structure are of intellectual, emotional and volitional origin. Attitudes operate as filters between objective reality stimuli and personal equation, being the "invariant under which the individual gets oriented selectively, adjusts himself according to preferences, thus adapting by evolving."

Measiscev (apud. Zlate, 2006) says that attitude has two important segments in its structure: an" incitative - orientative segment," for selection and evaluation, and an "effector", executive and volunteer segment. For consistency and unity in behavior, the two segments should be consistent with each other, and cooperative, too, which 


\section{"Mircea cel Batran" Naval Academy Scientific Bulletin, Volume XIX - 2016 - Issue 2 The journal is indexed in: PROQUEST I DOAJ / Crossref / EBSCOhost / INDEX COPERNICUS / DRJI / OAJI I JOURNAL INDEX I I2OR / SCIENCE LIBRARY INDEX / Google Scholar / Academic Keys/ ROAD Open Access I Academic Resources / Scientific Indexing Services / SCIPIO / JIFACTOR}

aspect can be translated as "the unity between word and deed."

In situations of antagonism, contradictions or even mutual exclusion, the dominant segment will adopt the specific nature of the behavior conduct. Thus, if the intellectual and emotional segment is more developed, the person will be more inconsistent, will leave the task, will hardly finish their work; conversely, when the voluntary sector is dominant, impulsive incongruous, reactions are observed.

A particularly important aspect in the leader's formation as personality and in the way he understands and is able to exert influence, is that attitudes should be understood in relation to their moral value. When they resonate positively with the social and progressive norms and laws, they are transformed into values. It is about what Linton called "the attitudes - values system" specific to each man and acting permanently unconsciously and involuntary, like an automaton. We tried to capture the mechanism to achieve social influence simultaneously with the cognitive, energy - emotional function, that act as a regulator of attitudes as sets of character traits so as to illustrate the intrinsic, indissoluble relationship of emotional intelligence that we place in the system of personality as a special skill, along with types general intelligence and creativity.

As a relatively new concept in the literature, emotional intelligence has often been described, in many studies, as a special form of intelligence, similar to those described by Gardner. I would dare to go further in examining the concept and noting that general intelligence is still a general skill, so, maybe more appropriate in addressing emotional intelligence would be to place ourselves within the area of aptitudes and to emphasize the interrelationships and deep inter - influences of all psychic structures, both the cognitive and the affective, motivational, and volitional ones.

From this perspective, we can highlight the prevalence of intellectual intelligence against emotional intelligence, with effective synergistic participation of all components of the psyche.

In defining the concept of emotional intelligence, we can summarize a few main areas: Mayer and Salovey $(1990,1993,1997)$ show that "in our paper work (1990), we have defined emotional intelligence according to the skills involved. Thus, in one of our first definitions, we considered emotional intelligence as the "ability to control their own feelings and the feelings of others; ability to distinguish between them and use this information to guide their own way of thinking and their actions.
"But, currently, this definition, like others, seem vague, incomplete, even lacking content, meaning that they only refer to observable emotion and how to adjust it, omitting feelings. Feelings, as higher, complex forms of affectivity with a high degree of awareness favor the optimal interactions of emotions and rationality. Also, emotional intelligence means the ability to understand and know emotions and regulating emotions so as to make them contribute to the intellectual and emotional development..."

The authors underline the compatibility relationship between cognition and affectivity with predominance of cognition which is able to understand and decipher the various emotional range, starting from the simplest emotions up to crystallized feelings or even passions. Hence, the adaptative adjustment.

From this perspective, the authors have developed several stages of emotional intelligence formation:

- perceptive evaluation and expression of emotion;

- facilitating the emotional thinking;

- understanding and analyzing emotions. Using emotional knowledge;

- regulation of emotions to promote emotional and intellectual growth.

Another direction for addressing emotional intelligence is provided by R. Bar-On (2011), who describes several components there of emotional intelligence:

- intrapersonal aspect - the key to emotional intelligence - referring to the awareness of their own emotions, optimism and assertiveness, respect, self-realization and independence;

- interpersonal aspect comprising: empathy, interpersonal relationships and social responsibility;

- adaptability with its resources: problem solving, reality testing and flexibility.

- stress control which involves: stress tolerance and impulse control;

- general disposition involving happiness and optimism.

A similar analysis registry is offered by Jeanne Segal (1999), who describes the components of emotional intelligence as follows:

- emotional consciousness;

- acceptance;

- emotional active awareness;

- empathy.

Perhaps the most prolific author to have dedicated himself to the study of the topic of emotional intelligence was D. Goleman (1995, 1996, 2004, 2007, 2008). In his work "Emotional Intelligence in Leadership" (2007, p.62), the author reveals 


\section{"Mircea cel Batran" Naval Academy Scientific Bulletin, Volume XIX - 2016 - Issue 2 The journal is indexed in: PROQUEST / DOAJ / Crossref / EBSCOhost / INDEX COPERNICUS / DRJI / OAJI / JOURNAL INDEX I I2OR / SCIENCE LIBRARY INDEX / Google Scholar / Academic Keys/ ROAD Open Access I Academic Resources / Scientific Indexing Services / SCIPIO / JIFACTOR}

personal skills and social skills, as "leadership skills", essential for the leader to exercise his leadership in its mission of positive psychological influence of the team.

Personal skills as skills, "refer to the manner in which we handle ourselves", self-knowledge and self-control being the most important while social skills "refer to the manner in which we manage our relationships" and include: social awareness and managing relationships.

As Goleman states (2007, p. 314), the leaders who build excellence must be open to knowing their own personality by:

- emotional self-knowledge, focusing on understanding their own emotions not only as a disruptive source but also as everlasting resource that supports performance, as support to intuition, values, beliefs that allow the leader to implement them and to follow his vision, his goal;

- accurate self-evaluation, a true self-assessment of one's own value and limits based on feedback and constructive criticism from others, wrapped in a healthy part of humor;

- self - confidence, potentiating the strengths and their connection to high aspiration levels, slightly higher than their moment possibilities;

Another pillar on which painstakingly to build personal skills as leadership skills is "self-control" a concept operationalized by Goleman (p.315) on several levels of analysis:

- self-control, propensity for positive emotions as energetic support and delay or even exclusion of negative emotions even turning negative emotions into positive ones, especially in crisis situations even stress.

- transparency, the ability of the leader to reveal himself/herself, to function psychologically in line with their own values, equally accepting both success and failure;

- adaptability, through increased tolerance to uncertainty and ambiguity, maintaining emotional awareness, situational or multicultural awareness, flexibility to inherent changes of the external environment;

- ambition, whose "emblem is lifelong learning", suggests the setting of high aspiration levels supported by a proportional intrinsic motivation which is to avoid over - or under - motivation for success, both damaging and generating failure.

- initiative, nicely combining creativity and controlled risk, the leader discovering new, unfamiliar ways to exploit opportunities and strengthen the sense of effectiveness to himself and his team;

- optimism, refers to the reconciliation of opposites achieved by healthy psychological balance, a situation which enables the leader to intuit the

DOI: 10.21279/1454-864X-16-12-005

(c) 2015. This work is licensed under the Creative Commons Attribution-Noncommercial-Share Alike 4.0 License. positive aspects of a challenging situation, he himself being focused on the positive and not on their negative doublet.

In analyzing social skills of leadership, Goleman (2007, p. 316), similarly describes professional skills, fathoming two fundamental pillars: social awareness and relationship management.

Social consciousness is operationalized through structured dimensions but operating unitary and integrative, as one:

- empathy, a concept taken from C. Rogers, means the ability to bring psychological rendition into others' frames of reference, the author referring both to emotional empathy (feeling what the other feels) and the cognitive empathy (thinking what the other thinks);

- organizational awareness, the leader's ability to intuit informal relationships beyond the surface, the games between authority and power on all levels of the group, organization or society;

- solicitude, the essential skill in creating a sustaining social professional work environment, generating satisfaction and work performance.

The other debate range on which $D$. Goleman (p.317) insists, refers to managing relationships, similar to managing emotions and consists of:

- inspiration, the leader as an inspirational source presumes his ability to synthesize in a generalized statement the following: aspirations, motives, beliefs, interests followers thus creating a personal vision which is the vision of all those who follow him;

- Influence, made as art of expressing psychosocial mechanisms of achieving it, whether it is spontaneously triggered as it happens in: imitation, taint, social comparison, cognitive dissonance, normative pressure, or psychosocial mechanisms of creating influence led by the leader in full awareness: persuasion, suggestion, regulatory mandate, control, order. As effects of social influence, psychological literature confirms by experiment and lists: uniformity, conformity and obedience.

- training others, meaning mentoring and counseling, that requires a good psychological knowledge of subordinates, an accurate assessment of skills, talents, motivations, their interests as well as an adequate distribution of work tasks according to their potential.

- facilitating change, openness to newness and progress, constant adjustment to changes in the working environment, as well as in social, cultural, organizational political environment, generating options and alternatives that would facilitate change; 


\section{"Mircea cel Batran" Naval Academy Scientific Bulletin, Volume XIX - 2016 - Issue 2 The journal is indexed in: PROQUEST / DOAJ / Crossref / EBSCOhost / INDEX COPERNICUS / DRJI / OAJI / JOURNAL INDEX I I2OR / SCIENCE LIBRARY INDEX / Google Scholar / Academic Keys/ ROAD Open Access I Academic Resources / Scientific Indexing Services / SCIPIO / JIFACTOR}

- conflict management, through the practice of genuine negotiation techniques, based on Socratic assumption that truth is not only on the side of a party involved in the conflict but also in front of everyone. This requires the ability to enunciate and restate a common objective by which all those involved could virtuously hold;

- teamwork and collaboration facilitating working relationships among colleagues, especially those of cooperation, collaboration, competition, group cohesion.

We can analyze the way specific traits of emotional intelligence acts as an important variable in the mixed example of exercised leadership within the naval domain. This is so we could equate the peculiarities of emotional intelligence and the specific of the operational naval leadership.

We advocate the mixed example, eclectic within the naval operational leadership, as a viable model from a practical perspective that emphasizes the complex realistic relationships of a leader as well as the work situation where the number of objective and subjective factors in achieving leadership is variable and standing permanent change.

The interaction between the personality of the leader and the complexity of the situation should not be interpreted from a mechanical point of view but from a dynamic point of view meaning that the leader can influence the situation through the essential features of his personality where emotional intelligence is an essential variable, being able to take possession of the situation, to restructure it, to make it a benefit to himself and to the team he leads. Yet, the situation may require fundamental dimensions of the leader's personality, capitalizing them and valorizing them to the fullest. It is, therefore, a relationship of dialectical unity between these variables of the mixed kind of leadership that fosters mutual adaptation going forth to performance and human professional efficiency.

The naval environment requires a series of psychological knowledge, often unmanageable, even for a balanced, mature and up-to-date personality: the ship as a physically narrow space, her motions (rolling and pitching), the hydro meteorological conditions, the watch keeping activities with psycho physiological repercussion, danger, risk and uncertainty that lurk anywhere in the vastness of the oceans, isolation for relatively long periods, complex professional demands requiring intense psychological stress, quick adjustment and re-adjustment to the norms, values and psychosocial climate of a group with specific features, and the list can go on.

Paraphrasing D. Goleman, the mixed model of leadership could be supported by four main pillars: leader, situation, team and communication. Simple research of the internal structure of each pillar reveals urgent need of emotional presence of all components of the field described by the researchers observe.

All in all, the leader's personality stands in the foreground, a fundamental binding agent in this model: temperament, skills, character, general intelligence and, above all, emotional intelligence, creativity as special skills of the leader's personality and its correspondents: making decision, motivating subordinates, leadership styles, keeping a good balance between authority - assertiveness - types of power, workload and automation...

The situation in which operational naval leadership is exercised requires adaptability with increased emotional awareness, situational and multicultural awareness, adaptive responses to change, to situation of crisis, the ongoing of what we call, using a sintagma, "an organization that learns".

The team of professionals of the naval group describes the issue of a small group, such as the ship's crew, with its peculiarities: forming the team by correctly using the formation stages, interpersonal relationships, culture and work climate, the objective being to build effective team work.

Another important pillar is maritime communication, usually in English considered as being other than their mother tongue, with notable psychological, social cultural implications, authentic communication and assertiveness techniques. Looking at the dynamic of just these few factors, as variables of the mixed model of leadership, we realize the huge complexity of the relationship in question and necessity of emotional intelligence as a key variable and facilitating factor in building of human and professional excellence by the naval leader.

\section{CONCLUSIONS}

Understanding the meaning and major role of emotional intelligence components in structuring and becoming of the naval leader's personality, with direct implications in building leadership excellence, in increasing the effectiveness and safety of naval security, the authors in the domain agreed, in a consensus, on the systeamtic training referring the development of skills and competences of emotional intelligence. 
"Mircea cel Batran" Naval Academy Scientific Bulletin, Volume XIX - 2016 - Issue 2

The journal is indexed in: PROQUEST / DOAJ / Crossref / EBSCOhost / INDEX COPERNICUS / DRJI / OAJI I

JOURNAL INDEX I I2OR / SCIENCE LIBRARY INDEX / Google Scholar I Academic Keys/ ROAD Open Access I

Academic Resources / Scientific Indexing Services / SCIPIO / JIFACTOR

There have already been developed effective preventive strategies and interventions to improve emotional competence and performance in the workplace. It is a set of "practices of choice" for the explicit purpose of development and changing of behavior change that have been proven effective in building programs in various fields.

A remarkable success of programs developing skills of emotional intelligence has been recorded, so far, in areas such as training and management training, formation and training of medical personnel, which help the trainees how to manage conflicts, along with programs for stress management or programs for the unemployed.

The pragmatic transposition of a comprehensive program of emotional intelligence skill development would help enormously the formation, development and excellence of the intelligent naval leader; this will also have direct effect on his team or organization, in its entirety. The relationship between emotional intelligence of the naval leader and emotional intelligence of the organization might generate ambitious projects that would converge and enrich the quality of the naval leadership.

\section{BIBLIOGRAPHY}

[1] Adair, J., Leadership strategic, Ed. Meteor Publishing, București, 2015.

[2] Adair, J., Cum să formezi lideri, Ed. Meteor Publishing, București, 2015.

[3] Bar-On,R., Parker, J:, Manual de Inteligență Emoțională, Ed. Curtea Veche, București, 2011.

[4] Cristea,D., Tratat de psihologie socială, Ed.TREI, București, 2015.

[5] Goleman, D., McKee,A., Boyatzis, R., Inteligența emoțională în Leadership, Ed.Curtea Veche, București, 2007.

[6] Goleman, D., Inteligența emoțională, cheia succesului în viață, Ed.ALLFA, București, 2008.

[7] Lazarus, R., Emoție și adaptare, Ed. TREI, București, 2011.

[8] Maxwell, J., Totul despre Lideri, Atitudine, Echipă, Relații, Ed. Amaltea, București, 2005.

[9] Mayer, J.D., Salovey, P., Emotional Intelligence and the construction and regulation of feelings, in Applied \&Preventive Psychology, UK: Cambridge University Press., p. 4, 197-208, 1995.

[10] Segal, J., Dezvoltarea Inteligenței Emoționale, Ed. Teora, București, 2004.

[11] Zlate, M., Fundamentele psihologiei, Ed. Universitară, București, 2006 